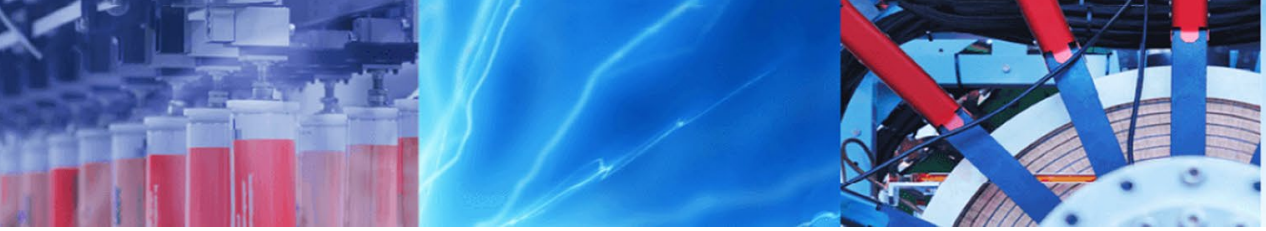

Research Article

\title{
Integrated treatment of municipal wastewater using advanced electro-membrane filtration system
}

\author{
Mona A. Abdel-Fatah ${ }^{1}$ (D) H. H. Shaarawy ${ }^{1}$. S. I. Hawash ${ }^{1}$
}

(c) Springer Nature Switzerland AG 2019

\begin{abstract}
Treatment of municipal wastewater using advanced physicochemical process maximizes the removal of biological oxygen demand $\left(\mathrm{BOD}_{5}\right)$, chemical oxygen demand (COD) and phosphate. Also discarding of suspended solids using nano adsorbent then electrochemical treatment, followed by ultra-filtration membrane was conducted. So, treated wastewater can be reused for agriculture of non-edible or wood trees, fishes, livestock and sheep farming. The results showed that: $\mathrm{BOD}_{5}, \mathrm{COD}$, and phosphates percent removal of $93 \%, 95 \%$ and $100 \%$ respectively. Using mini hydro turbine of power generation about $1.5 \mathrm{kwt} / \mathrm{h}$ and with a flow rate of $10-15 \mathrm{~L} / \mathrm{s} .50 \%$ of the energy consumption could be recovered by rotation of the mini hydro-turbine using reject flow. Construction and operating costs of sewage treatment plants can be reduced up to $50 \%$ compared with that of traditional low-efficiency biological treatment plants. Sludge produced from the advanced proposed process in this investigation can be used as fertilizer due to its quality while that produced from the traditional treatment process is unsafe to reuse.
\end{abstract}

Keywords Wastewater treatment $\cdot$ Nano adsorbent $\cdot$ Electro-coagulation $\cdot$ Membrane filtration

\section{Introduction}

Water next to air is the most important element for living organisms (human, plant, animal), it cools body and transports nutrients and wastes. There is an inverse relationship between the water quantity, quality, and the pattern of consumption with the diseases spreading. Currently, the world does not suffer from a lack of water resources as much as the unequal distribution of freshwater according to the geographical location where hundreds of millions of people do not have access to clean water to meet their basic needs. On the other hand, various industries, agriculture, and sanitation produce large amounts of wastewater, which account for at least $50 \%$ of the amount of clean water produced to meet human needs worldwide [1]. This wastewater needs to be treated before discharge into surface water systems. Biological wastewater treatment systems were the dominant treatment systems [2-6] until the late 1980s, all over the world especially in Egypt which uses the biological treatment up till now.

Egypt suffers from water shortages, where the annual water income is about 55.5 billion cubic meters since 1969 in spite of the escalating population growth. This leads to a lack of annual per capita water share which reached to 611 cubic meters in 2015 which is of course; under the global water poverty line [7-10].

Egypt is looking for new sources for water, and the concept of recovery, treatment, and re-use is one of the proposed solutions to resolve the problem of water scarcity in Egypt. The annually produced sewage water amounts to 9 billion cubic meters is considered one of the most important sources of permanent and processors that can be reused for irrigation $[8,9]$. Due to the high content of $\left(\mathrm{BOD}_{5}\right)$, (COD) and suspended solids (SS), so biological, chemical and physical composition of sewage water cannot permit

Mona A. Abdel-Fatah, monamamin7@yahoo.com | ${ }^{1}$ Chemical Engineering and Pilot Plant Department, National Research Centre, Cairo, Egypt.

SN Applied Sciences (2019) 1:1153 | https://doi.org/10.1007/s42452-019-1178-9

Received: 16 April 2019 / Accepted: 28 August 2019 / Published online: 4 September 2019

SN Applied Sciences

A SPRINGER NATURE journal 
it to be discharged into water body because it will cause severe pollution on a big scale [10].

Currently, the use of non-biodegradable materials and chemicals, the efficiency of biological treatment has fallen to low levels. On the other hand, the capital costs of setting up biological treatment plants and their operating costs are very expensive, high consumption of the huge amount of air for aeration process, as well as high consumption of electric energy causing carbon dioxide emissions, leads to global warming. Finally, biological treatment plants required with a high price which is not available [11].

To protect the environment and freshwater resources improper treatment technique for sewage water treatment must be done [11]. It is urgent to substitute the conventional, expensive and complex treatment method used in Egypt by an efficient, affordable and simple treatability procedure [12]. Due to growing awareness of problems associated with sewage treatment plant effluent worldwide, we must take into consideration to control inadvertent organic, enrichment of nitrogen \& phosphorus as pollutants in surface and groundwater [13].

Based on all the above-mentioned reasons, the whole world is looking for cost-effective novel physical-chemical technologies that overcome the defects of biological treatments. These technologies should be easy to implement and control, cheap in construction and operation costs, highly efficient, environmentally friendly, and implemented on small areas of land with low energy consumption. Several novel technologies meet the previous requirements such as electrochemical oxidation, electro-coagulation EC, electrodialysis ED, photo-electrooxidation, electrochemical disinfection and sterilization, membrane filtration (ultra-filtration, nano-filtration, and reverse osmosis) as well as nano-adsorbents [14-23]. The integrated and hybrid treatment systems based on these technologies provide an ideal solution for the desired target.

Advanced treatment of sewage water (electro-coagulation) followed by membrane filtration (MF/UF/RO) represents one of the most promising technologies for sewage water treatment to make it suitable for aquaculture growing followed by agriculture produced crops. Reverse osmosis (RO), membrane filtration (MF) and combined coagulation-disk filtration (CC-DF) were continuously operated at Ansan wastewater treatment plant (Ansan, Gyeonggi-do, Korea), as shown in Fig. 1 [24]. The study novelty depends on the optimization of selected sewage water treatment system utilizing electro-coagulation, microfiltration, ultrafiltration, and reverse osmosis as new trends in treatments.

Electro-coagulation is one of the simple and cost-effective methods to treat wastewater efficiently. It seems to be an adequate technique due to its high efficiency and rapid achievements with lower labor needs and less operating costs. Electro-coagulation can treat different types of wastewaters e.g. restaurant wastewater, food wastewater, palm oil mill effluent, tannery wastewater, dyes wastewater, and potato chip manufacturing wastewater. In spite of using metal salts or polymers as coagulants for breaking the pollutants, electro-coagulation treatment processes can be used because the electrode can generate coagulated species and metal hydroxides that destabilize and aggregate the suspended particles then precipitate them. This is due to hydrogen gas released from the cathode which helps to aid the flocculated particles to float out at water surface [25-29].

The rate of fluid filtration is determined according to the size of the pores of the membrane and UF is known as a process between MF, UF, NF [30] and RO membrane, because UF membranes usually have pores in the range of 10-1000 $\AA$. Larger particles pass less through the membrane with smaller pores size. Accordingly, membranes are also capable of disposing of particles in the molecular weight range of $300-500,000$. These membranes are capable of removing sucrose, bio-molecules, polymers, and colloidal particles.

Sewer wastewater reclamation gave excellent results when it is treated with RO membrane due to its high
Fig. 1 Pilot plant flow sheet of the CC-DF, MF and RO membranes [24]

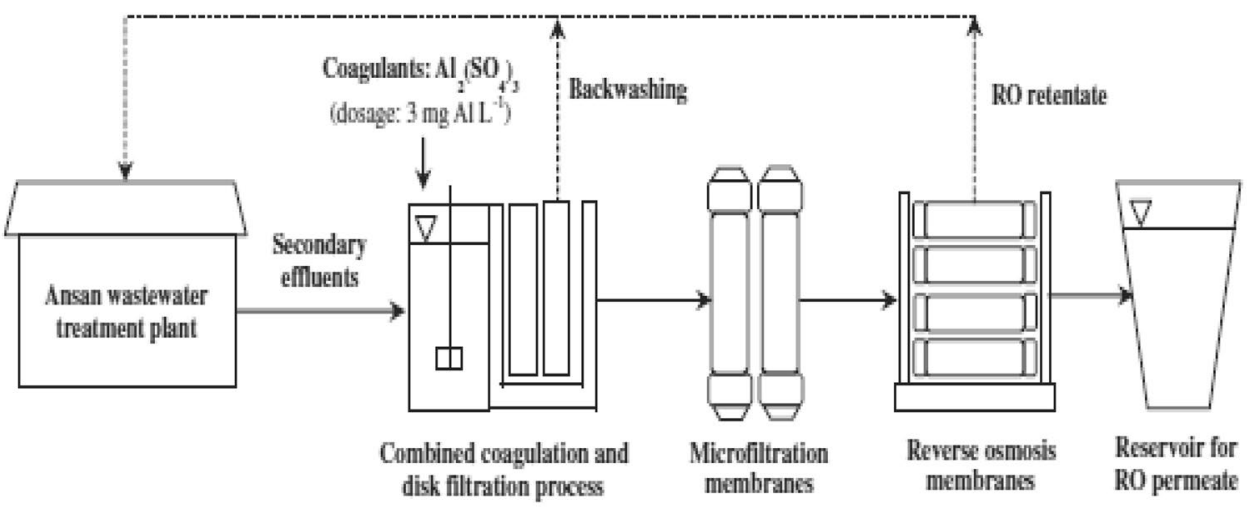


removal efficiency of pollutants, stable water quality and easy operation [31-38]. The RO systems are designed to operate at high permeate flux rate to obtain long term stable membrane performance. The investment and operating costs are similar to those of typical brackish water RO systems. Recently a new pretreatment technology has been introduced for RO processing of municipal effluent which consists of back washable microfiltration, ultrafiltration, and nano-filtration membrane elements in a capillary configuration.

Electrochemical disinfection has been studied and utilized for several decades as an effective water purification method, because it is an easy, low-cost method that has been proven to inactivate a variety of microorganisms, including different types of bacteria and viruses. Electrochemical disinfection can be done by either of two methods: direct in-line electrolysis and onsite generation of reactive oxygenated species. The second method uses a mixture of disinfecting species, including several oxidizing compounds, generated in an on-site electrochemical cell and added to a water stream. The onsite generation of mixed oxidant as electrolytic water disinfection has the advantage over direct inline disinfection [39].

Based on hard and continuous investigations of our research team for more than 15 years, it was found that integrated system of adsorption over nano-iron prepared by electro-coagulation, followed by membrane filtration, then electrochemical disinfection will represent highefficiency wastewater treatment process. This innovative system will overcome the week efficiency of the traditional biological treatment process, also leads to cost-effective, easy controlled, low capital cost physical-chemical technology. The obtained treated water could be classified to different purity grades due to the type of membrane used. Also in the field of municipal wastewater, the generated sludge could be proceeded to obtain high-quality fertilizers while in the industrial and irrigation wastewaters the generated sludge could be dried and used in the cement industry. Thus these integrated treatment units could be classified as zero liquid discharge (ZLD) systems.

\section{Process description}

The treatment process within the integrated system could be described as follow:

- Raw sewage water is passed through a grid screen for large size particles removal then the screened water is directed to the oil trap for free oils separation.

- Then water is pre-conditioned (by adjusting TDS, pH... others) to be ready for electro-coagulation active nano iron formation step.
- Then conditioned water is directed to the electrocoagulation cell where the direct current in the bath dissolves the iron anodes and reduces the generated ferric ion by sodium boron hydride to nano iron.

- Water from the electro-coagulation cell containing active nano iron is mixed with alkaline activated Aswan clay for several minutes.

- After adsorption takes place, the $\mathrm{pH}$ is neutralized to get high-density flocks.

- The clarification followed by settling steps takes place.

- Clearwater from the selling tank is subjected to sand filter followed by activated carbon filtration and finally ultra-filtration unit to get treated water.

- Disinfection using the electro generated mixed oxidants of treated water takes place.

- Disinfected water was subjected to complete analyses before discharging to River Nile to be sure that their characteristics are within the permissible governmental rules.

- The settled sludge can be formed to chelated iron fertilizer after mixing with a definite quantity of certain organic acids to dissolve iron.

- The slurry is then filtered to get chelated iron fertilizer solution and highly organic value solid fertilizer.

- The feed electricity to powering the treatment plant is subjected to nano-graphene super capacitor energy saver which makes the shift angle between the current and voltage zero to save $30 \%$ of the consumed energy.

- During passing water through the pipes of the plant, several mini-hydro turbines for electric power recovery were placed, which could recover $60 \%$ of the total power consumed.

- The system is fully automated and controlled by the control panel.

\section{Pilot scale treatment unit}

\subsection{Units description}

\section{- Screen}

This unit is consisted of two parallel screens, of rectangular shape and inclined on the horizontal plane by $60^{\circ}$ to remove big floated matters, such as papers, textiles, wooden pieces, etc. of particle size more than $0.2 \mathrm{~mm}$. The cleaning of screens will proceed manually and raked for dewatering on the perforated platform.

\section{- Grit chamber and oil trap}

Two parallel long channels with a rectangular crosssection were designed to remove big particles to protect mechanical parts and pipes from abrasion and 
wear. The proportion between the cross-section of the channel and the weir controls the velocity of flow inside it. The grits will be cleaned by a manual scraper in a hopper containing the sand dewatering valve that will remove sand to the sand barrel.

- Electro-coagulation cell

It is an anodic dissolution cylindrical cell constructed from PVC with iron electrodes of the active surface area of $250 \mathrm{~cm}^{2}$. It is of $50 \mathrm{~L}$ volume with flow rate $100 \mathrm{~L} / \mathrm{h}$.

- Power supply

It consists of DC power supply; with digital display and of variable current control from 0 to $75 \mathrm{~A}$ and variable voltage control of $0-100 \mathrm{~V}$.

- Ultrafiltration unit

Ultrafiltration unit (cross-flow type) of 100-L capacity produced by GE Company specialized for sewage water filtration.

- Flash mixing tank

In this tank, screened raw water is mixed with coagulants then it is thoroughly agitated. The chemicals introduced into the water stream will attract very fine particles, such as silt and then they were flocculated to form heavier flocks which are much easier to settle down. In the flocculation process, the rapid mixing is specially designed to disperse polymers so they enhance the flocculation process. Rapid mixing is used for violent agitation of wastewater with the coagulants for a short time before releasing into the flocculation basin.

- Clarifier

This unit is designed to clarify water from stabilized organic matters as suspended solids. It is a circular tank with an inclined bottom by $45^{\circ}$. Radial flow from the control settling chamber to the perimeter with inlet pipe which enters the settling chamber and the outlet water is taken from the overflow weir. It is equipped with outlet pipes for sludge removal using centrifugal pumps.

- Electrochemical disinfectant unit

Mixed oxidant generation cell of $5 \mathrm{~L}$ capacity and flow rate of $5 \mathrm{~g} / \mathrm{h}$, sodium hypochlorite with titanium iridium oxide coated modified electrode powered by DC power supply of 0-5 A current control and $0-24 \mathrm{~V}$ voltage control.

\subsection{Scaling up of treatment unit}

Optimum operating conditions which gave good treatment results were applied for the design of a treatment unit of bigger capacity (capacity of $120 \mathrm{~m}^{3} /$ day).

\subsubsection{Units components}

- Feeding pump Five pumps (4 in duties) each of $5 \mathrm{~m}^{3} / \mathrm{h}$ flow rate, Pressure: 5 bar, Material: St. St. 304.

- Primary clarifier for oils, greases, and dirt separation It is one cylindrical with a conical base tank $\left(5 \mathrm{~m}^{3} / \mathrm{h}\right)$, Continuous process and Retention time: $2 \mathrm{~h}$.

- Electrochemical cell Rectangular Shape, Steel lined PVC, Capacity: 500 L, Flow rate: $5 \mathrm{~m}^{3} / \mathrm{h}$, Hydrogen gas vent: present, Inlet/outlet: 4 ", plates electrode, iron electrode, \pm terminal.

- Power supply D.C power supply, 1000 A, 50 V, Current control, Voltage control, Digital current display, Digital voltage display, Polarity reversal with time adjustment, Air force cooling.

- Chemical dosing pumps Six pumps of flow rate: $0-7 \mathrm{~L} / \mathrm{h}$, Pressure up to 7 bars, and Dosing tank with $200 \mathrm{~L}$.

- Secondary clarifier One cylindrical tank with a conical base of $5 \mathrm{~m}^{3} / \mathrm{h}$ capacity, Continuous type, and retention time: $2 \mathrm{~h}$, Steel material.

- Balance tank Three cylindrical tanks each of $20 \mathrm{~m}^{3}$ capacity, Material of construction: steel.

- Multimedia filter One cylindrical steel filter $\left(5 \mathrm{~m}^{3} / \mathrm{h}\right)$, Media: sand, gravel, anthracite, activated carbon.

- Micro cartridge filter Flow rate: $5 \mathrm{~m}^{3} / \mathrm{h}$, Material of construction: polypropylene, Diameter: 2 ", Length: $10^{\prime \prime}$.

- UF filtration One module of $5 \mathrm{~m}^{3} / \mathrm{h}$, flow rate, one housing with 4" diameter and Working pressure 1.2 bar.

- Disinfection dosing system Electrochemical disinfector of $10 \mathrm{~g} / \mathrm{h}$ capacity.

- Sludge thickening tank Material of steel, cylinder, Capacity: $1 \mathrm{~m}^{3}$.

- Sludge transferring pumps Material of St. St. 304 and $5 \mathrm{~m}^{3} / \mathrm{h}$.

- The mini-hydro turbine of power generation about $1.5 \mathrm{k} \mathrm{wt} / \mathrm{h}$ and with a flow rate of $10-15 \mathrm{~L} / \mathrm{s}$.

- Control panel.

- Required area $\left(300 \mathrm{~m}^{2}\right)$.

\section{Results and discussion}

Figure 2 represents the flow diagram of the advanced system for sewage treatment process using the integration of anodic dissolution of iron electrode followed by reduction using sodium boron hydride to get highly active nano iron 


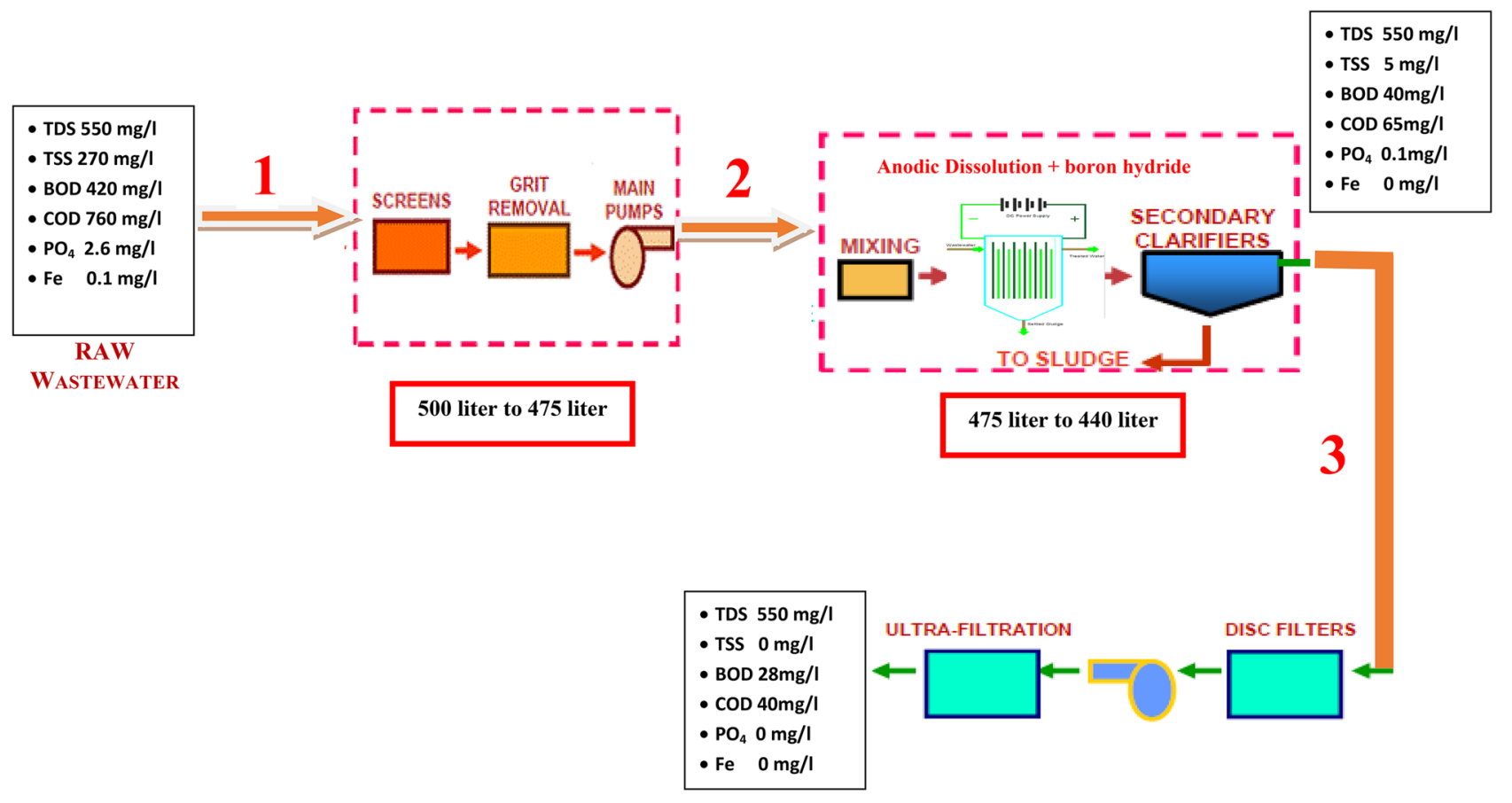

Fig. 2 Flow diagram of the proposed system

which is mixed with activated clay followed by neutralization and sedimentation for complete removal of total suspended solids, and dissolved phosphates. After clarification, the clarified water is then subjected to Ultrafiltration membrane step to get treated water with the best characteristics which can be used for irrigation and fish farming. The results obtained from the tested system are illustrated below.

As clear in Fig. 2; in the first step screening and girt removal was carried out to remove large bodies such as sand and gravels from the feed wastewater. Then the wastewater mixed with boron-hydride and when the electric current passes in the electrocoagulation cell nano-iron formed by anodic dissolution and by reaction with water nano-ferric hydroxide formed as a gelatinous film when settling down all the suspended solids will be removed. Also, the active ferric hydroxide will react with phosphorous forming insoluble iron phosphate leading to complete removal of phosphorous from the treated water to prevent the clogging of the water channels because phosphorous encourages the growth of the plants.

The direct current passes through the electrocoagulation cell will cause preliminary disinfection of the feed water. At the ultrafiltration step, died bacteria, high molecular weight dissolved organic pollutants will be rejected. At the RO step, the dissolved salts will be completely removed then by adding the electro-generated mixed oxidant generated through the electro catalytic disinfection step very safe water will be obtained. The mechanism of the electrocoagulation process using iron anode and the mechanism of mixed oxidant formation will be explained by the following equations:

(A) Electrocoagulation mechanism

$$
\begin{aligned}
& 2 \mathrm{Fe}_{(\mathrm{s})}-4 \mathrm{e}^{-} \rightarrow 2 \mathrm{Fe}_{(\mathrm{aq})}^{+} \quad\left(\mathrm{E}^{\circ}=+0.447 \mathrm{~V}\right) \\
& \mathrm{Fe}_{(\mathrm{s})}-3 \mathrm{e}^{-} \rightarrow \mathrm{Fe}_{(\mathrm{aq})}^{3+} \quad\left(\mathrm{E}^{\circ}=+0.037 \mathrm{~V}\right) \\
& \mathrm{Fe}_{(\mathrm{aq})}^{2+}-\mathrm{e}^{-} \rightarrow \mathrm{Fe}_{(\mathrm{aq})}^{3+} \quad\left(\mathrm{E}^{\circ}=-0.771 \mathrm{~V}\right) \\
& \mathrm{Fe}_{(\mathrm{aq})}^{2+}+2 \mathrm{OH}_{(\mathrm{aq})}^{-} \rightarrow \mathrm{Fe}(\mathrm{OH})_{2(\mathrm{~s})} \\
& 2 \mathrm{Fe}_{(\mathrm{aq})}^{3+}+6 \mathrm{OH}_{(\mathrm{aq})}^{-} \rightarrow 2 \mathrm{Fe}(\mathrm{OH})_{3(\mathrm{~s})}
\end{aligned}
$$

As clear from the above equations nano-ferric hydroxide gelatinous film is formed which causes the removal of suspended solids [40].

(B) Phosphorous removal mechanism

$3 \mathrm{Fe}^{+2}+2 \mathrm{PO}_{4}^{-3} \rightarrow \mathrm{Fe}_{3}\left(\mathrm{PO}_{4}\right)_{2} \downarrow$

The above mention equation shows the removal of phosphorus by precipitation with ferrous ion formed by electrocoagulation process [40]. 
(C) Electro-catalytic disinfection mechanism [39].

$\mathrm{O}_{3}$ can be generated by the reaction of $\mathrm{O}_{2}$ with $\mathrm{O}$. Hypochlorite together with ozone and hydrogen peroxides as mixed oxidants, which are the main products of electrolysis due to the high disinfecting ability of these species as clear from the following equations.

$\mathrm{H}_{2} \mathrm{O} \rightarrow \mathrm{OH}^{\cdot}+\mathrm{H}^{+}+\mathrm{e}^{-}$

$\mathrm{OH}^{\cdot} \rightarrow \mathrm{O}^{-}+\mathrm{H}^{+}+\mathrm{e}^{-}$

$2 \mathrm{O} \rightarrow \mathrm{O}_{2}$

$\mathrm{O}+\mathrm{O}_{2} \rightarrow \mathrm{O}_{3}$

$\mathrm{OH}+\mathrm{OH}^{-} \rightarrow \mathrm{H}_{2} \mathrm{O}_{2}$

$\mathrm{NaCl} \rightarrow \mathrm{Na}^{+}+\mathrm{Cl}^{-}$

Also hypo-chlorous acid and per chlorate could be generated according to the following equations:

$\mathrm{Cl}_{2}+2 \mathrm{OH}^{-} \longrightarrow \mathrm{ClO}^{-}+\mathrm{Cl}^{-}+\mathrm{H}_{2} \mathrm{O}$

$2 \mathrm{ClO}^{-}+2 \mathrm{H}_{2} \mathrm{O} \longrightarrow 2 \mathrm{ClO}_{3}^{-}+4 / 3 \mathrm{Cl}^{-}+2 \mathrm{H}^{+}+1 / 2 \mathrm{O}_{2}$

$2 \mathrm{ClO}^{-}+2 \mathrm{H}_{2} \mathrm{O} \longrightarrow 2 \mathrm{HClO}+2 \mathrm{OH}^{-}$

$2 \mathrm{HClO}+\mathrm{ClO}^{-} \longrightarrow \mathrm{ClO}_{3}^{-}+2 \mathrm{Cl}^{-}+\mathrm{H}^{+}$

$\mathrm{HOCl}+\mathrm{O}_{3} \longrightarrow \mathrm{ClO}_{2}^{-}$

$\mathrm{HOCl}+\mathrm{H}_{2} \mathrm{O}_{2} \longrightarrow \mathrm{H}_{2} \mathrm{O}+\mathrm{O}_{2}+\mathrm{Cl}^{-}+\mathrm{H}^{+}$

$\mathrm{HOCl}+2 \mathrm{ClO}_{2}+\mathrm{H}_{2} \mathrm{O} \longrightarrow 2 \mathrm{ClO}_{3}^{-}+\mathrm{Cl}^{-}+3 \mathrm{H}^{+}$

$\mathrm{HOCl}+2 \mathrm{ClO}_{2}^{-}+\mathrm{H}^{+} \longrightarrow 2 \mathrm{ClO}_{2}+\mathrm{H}_{2} \mathrm{O}+\mathrm{Cl}^{-}$

$2 \mathrm{HOCl}+\mathrm{ClO}_{2}^{-} \longrightarrow \mathrm{ClO}_{3}^{-}+\mathrm{Cl}_{2}+\mathrm{H}_{2} \mathrm{O}$

$2 \mathrm{OH}^{-}+\mathrm{O}_{2} \longrightarrow 2 \mathrm{HOO}^{-}$

Cathode:

$2 \mathrm{O}_{2}+4 \mathrm{e}+\mathrm{H}_{2} \mathrm{O}_{2} \longrightarrow 2 \mathrm{HOO}^{-}+2 \mathrm{OH}^{-}$

Anode:

$4 \mathrm{OH}^{-} \longrightarrow 2 \mathrm{H}_{2} \mathrm{O}_{2}+\mathrm{O}_{2}+4 \mathrm{e}$

\subsection{Water quality}

As it is clear from the results shown in Fig. 2 that: the COD, $\mathrm{BOD}_{5}$, TSS and phosphates removal efficiency till filtration step were $91.5 \%, 90.5 \%, 98.15 \%$ and $96.15 \%$, respectively. While adding ultra-filtration step, the removal efficiencies increased to $94.74 \%, 93.33 \%, 100 \%$ and $100 \%$ respectively

Table 1 The proposed system electricity

\begin{tabular}{llll}
\hline Treatment stage & $\begin{array}{l}\text { Electric- } \\
\text { ity cons. } \\
(\mathrm{k} \mathrm{wt} / \mathrm{h})\end{array}$ & $\begin{array}{l}\text { After energy } \\
\text { saver }(\mathrm{k} \mathrm{wt} / \mathrm{h})\end{array}$ & $\begin{array}{l}\text { After energy } \\
\text { recovery } \\
(\mathrm{k} \mathrm{wt} / \mathrm{h})\end{array}$ \\
\hline Electro-coagulation & 1.6 & 1.1 & 1.1 \\
EC/UF membrane & 2.25 & 1.15 & 1.15 \\
\hline
\end{tabular}

Table 2 Running cost of the proposed system

\begin{tabular}{ll}
\hline Treatment stage & $\begin{array}{l}\text { Running } \\
\text { cost (LE/ } \\
\left.\mathrm{m}^{3}\right)\end{array}$ \\
\hline Electro-coagulation & 2.1 \\
EC and UF membrane & 2.5 \\
\hline
\end{tabular}

for $\mathrm{COD}, \mathrm{BOD}_{5}, \mathrm{TSS}$, and phosphates, and this water could be used for irrigation and fish farming.

\subsection{Power consumption}

The proposed pilot system will consume electricity for the successive treatment steps according to the following Table 1.

As it is clear from the power consumption values the energy saver will save about $31 \%$ where no energy could be recovered in this step, while in case of using ultrafiltration membrane about $49 \%$ of energy will be saved using the energy saver and mini-hydro turbine.

\subsection{Running cost}

The running cost of the proposed system concerning cubic meter of treated water will be as illustrated in Table 2.

\subsection{Comparison between proposed technology and traditional biological technology}

From Table 3 it is clear that: the proposed sewage water treatment advanced integrated system is overcoming all the disadvantages generated during the use of the traditional biological treatment process. So advanced integrated system reduces the treatment time from hours to a

Table 3 Comparing proposed technology and traditional Biological technology

\begin{tabular}{|c|c|c|}
\hline Item & Proposed system & Biological treatment \\
\hline Treatment time (h) & $10 \mathrm{~min}$ & $6-24 \mathrm{~h}$ \\
\hline $\begin{array}{l}\text { Power consumption } \\
\left(\mathrm{kwt} / \mathrm{m}^{3}\right)\end{array}$ & $1.1-2.25$ & $3-12$ \\
\hline Treatment cost $\left(\mathrm{LE} / \mathrm{m}^{3}\right)$ & 2.5 & $5-15$ \\
\hline Water quality & High quality & Moderate \\
\hline Sludge quality & Used as fertilizer & Unsafe \\
\hline Disinfection & $\begin{array}{l}\text { Low cost elec- } \\
\text { trochemical } \\
\text { disinfection }\end{array}$ & Chlorine gas \\
\hline Safety & Very safe & Unsafe \\
\hline
\end{tabular}


few minutes, the electric power consumption decreases to an average $70 \%$ of the power consumed at the traditional treatments. The reduction in treatment time and consumed power will reduce the area needed for treatment plant construction as well as the capital and running costs. From the other hand, the water quality of the obtained water from the advanced integrated system could be used for edible crops planting and in fish farming while treated water generated from the biological treatment process is only used for tree or forest planting.

Also obtained sludge from the integrated system is a high cash flow fertilizer, so it is the first time in which the sewage treatment sector becomes profitable instead of being a money consuming sector.

\section{Conclusions}

Novel and advanced treatment integrated system for domestic municipal wastewater is designed to overcome the disadvantages of the traditional biological treatment process. This system is based on the combination of anodic dissolution, nano adsorbents, ultrafiltration with energy-saving and recovery. The proposed integrated system presents a successful process for obtaining high-quality water with low capital, and running costs. Also, high cash flow fertilizers were produced from the obtained sludge from the clarification process. Finally, about $50 \%$ of the electric power used for system operation could be saved using energy saver by a minihydro turbine (power generation about $1.5 \mathrm{k} \mathrm{wt} / \mathrm{h}$ at a flow rate of 10-15 L/s). As a whole, the proposed system is one of the promising systems which give the safest water quality and saving energy at a cheaper cost.

\section{Compliance with ethical standards}

Conflict of interest The author declare that they have no competing interests.

\section{References}

1. Rajasulochana P, Preethy V (2016) Comparison of the efficiency of various techniques in the treatment of waste and sewage water: a comprehensive review. Resour Effic Technol 2:175-184

2. Dargahi A, Mohammadi M, Amirian F, Karami A, Almasi A (2017) Phenol removal from oil refinery wastewater using anaerobic stabilization pond modeling and process optimization using response surface methodology (RSM). Desalin Water Treat 87:199-208
3. Shokoohi R, Jafari AJ, Dargahi A, Torkshav Z (2017) Study of the efficiency of bio-filter and activated sludge (BF/AS) combined process in phenol removal from aqueous solution: determination of removing model according to response surface methodology (RSM). Desalin Water Treat 77:256-263

4. Shokoohi R, Gillani RA, Mahmoudi MM, Dargahi A (2018) Investigation of the efficiency of heterogeneous Fenton-like process using modified magnetic nanoparticles with sodium alginate in removing Bisphenol A from aquatic environments: kinetic studies. Desalin Water Treat 101:185-192

5. Almasi A, Dargahi A, Amrane A, Fazlzadeh M, Soltanian M, Hashemian A (2018) Effect of molasses addition as biodegradable material on phenol removal under anaerobic conditions. Environ Eng Manag J (EEMJ) 17(6):1475-1482

6. Shokoohi R, Movahedian H, Dargahi A, Jafari AJ, Parvaresh A (2017) Survey on the efficiency of BF/AS integrated biological system in phenol removal of wastewater. Desalin Water Treat 82(2017):315-321

7. Hussien NH, Shaarawy HH, Shalaby MS (2015) Sewage water treatment via electrocoagulation using iron anode. ARPN J Eng Appl Sci 10(18) ISSN 1819-6608

8. Abdel-Fatah MA, Elsayed MM, Al Bazedi GA, Hawash SI (2016) Sewage water treatment plant using diffused air system. J Eng Appl Sci 11(17):10501-10506

9. Wang J, Chen C (2009) Biosorbents for heavy metals removal and their future. Biotechnol Adv 27:195-226

10. Gijzen H (2002) Anaerobic digestion for sustainable development: a natural approach. Water Sci Technol 45:321-328

11. Grau P (1996) Integrated water and waste management. Water Sci Technol 33:39-46

12. Fan J, Tao T, Zhang J, You G-L (2009) Performance evaluation of a modified anaerobic/anoxic/oxic (A2/O) process treating low strength wastewater. Desalination 249:822-827

13. Lakshmanan R (2013) Application of magnetic nano-particles and reactive filter materials for wastewater treatment. Doctoral thesis, Royal Institute of Technology School of Biotechnology Stockholm

14. Segneanu $A E$, Orbeci $C$, Lazau $C$, Sfirloaga $P$, Vlazan $P$, Bandas $C$, Grozescu I (2013) Waste water treatment methods. Water Treat. https://doi.org/10.5772/53755

15. Naje AS, Abbas SA (2013) Electrocoagulation technology in wastewater treatment: a review of methods and applications. Civ Environ Res 3(11):29-42

16. Falsanisi D, Liberti L, Notarnicola M (2009) Ultrafiltration (UF) pilot plant for municipal wastewater reuse in agriculture: impact of the operation mode on process performance. Water 1:872885. https://doi.org/10.3390/w2040872

17. Mehta KP (2015) Design of reverse osmosis system for reuse of waste water from common effluent treatment plant. Int Res J Eng Technol (IRJET) 2(4):983-991

18. Tiwari DK, Behari J, Sen P (2008) Application of nano-particles in waste water treatment. World Appl Sci J 3(3):417-433

19. Stoimenov PK, Klinger RL, Marchin GL, Klabunde KJ (2002) Metal oxide nanoparticles as bactericidal agents. Langmuir 18:6679-6686

20. Akhter M, Habib G, Qamar SU (2018) Application of electrodialysis in waste water treatment and impact of fouling on process performance. J Membr Sci Technol 8:2. https://doi. org/10.4172/2155-9589.1000182

21. Sharma D (2014) Treatment of dairy wastewater by electrocoagulation using aluminum electrodes and settling, filtration studies. Int J ChemTech Res 6(1):591-599

22. Arega Y, Chavan RB (2018) Electrocoagulation followed by ion exchange or membrane separation techniques for recycle of textile wastewater. Adv Res Text Eng 3(2):id1024 
23. Chon K, Cho J, Kim SJ, Jang A (2014) The role of a combined coagulation and disk filtration process as a pre-treatment to microfiltration and reverse osmosis membranes in a municipal wastewater pilot plant. Chemosphere 117(1):20-26. https://doi. org/10.1016/j.chemosphere.2014.05.042

24. Bukhari AA (2008) Investigation of the electro-coagulation treatment process for the removal of total suspended solids and turbidity from municipal wastewater. Bioresour Technol 99:914-921

25. Kobya M, Demirbas E, Can OT, Bayramoglu M (2006) Treatment of levafix orange textile dye solution by electro-coagulation. J Hazard Mater 132:183-188

26. Hussein HS, Sabry R, Hassan N, Morsi MS, Shaarawy HH (2014) Removal of reactive blue dye 19 from textile wastewater by electrocoagulation using iron electrodes. Res J Pharm Biol Chem Sci RJPBCS 5(3):1

27. Sarala C (2012) Domestic wastewater treatment by electrocoagulation with Fe-Fe electrodes. Int J Eng Trends Technol 3(4):530-533

28. Saleem M, Bukhari AA, Akram MN (2011) Electro-coagulation for the Treatment of wastewater for reuse in irrigation and plantation. J Basic Appl Sci 7(1):11-20

29. Kurt U, Gonullu MT, Ilhan F, Varinca K (2008) Treatment of domestic wastewater by electro-coagulation in a cell with Fe-Fe electrodes. Environ Eng Sci 25(2):153-162

30. Abdel-Fatah MA (2018) Nanofiltration systems and applications in wastewater treatment: a review article. Ain Shams Eng J. https ://doi.org/10.1016/j.asej.2018.08.001

31. Singh R (2011) Analysis of energy usage at membrane water treatment plants. Desalin Water Treat 29:63-72

32. Kamp PC, Kruithof JC, Folmer HC (2000) UF/RO treatment plant Heemskerk: from challenge to the full-scale application. Desalination 131:27-35

33. Raffin M, Germain E, Judd S (2012) Assessment of fouling of an $\mathrm{RO}$ process dedicated to indirect potable reuse. Desalin Water Treat 40:302-308
34. Tang F, Hu H-Y, Sun L-J, Wu Q-Y, Jiang Y-M, Guan Y-T, Huang J-J (2014) Fouling of reverse osmosis membrane for municipal wastewater reclamation: autopsy results from a full-scale plant. Desalination 349:73-79

35. Sudak RG, Dunivin W, Rigby MG (1990) Municipal wastewater reclamation and reverse osmosis. In: Proceedings of the national water supply improvement association 1990 biennial conference, Florida August 1990, p 225

36. Ravazzini AM, van Nieuwenhuijzen AF, van der Graaf JHMJ (2005) Direct ultrafiltration of municipal wastewater: comparison between filtration of raw sewage and primary clarifier effluent. Desalination 178:51-62

37. Bruin D, Kamp F, Eddy P, Lagrand K (2002) WTW: UF/RO from technological novelty to the full-size application. In: Proceedings IWA Enviro 2002, Melbourne, Australia, 2002

38. Shaarawy HH, Saied M (2012) Production of sodium hypochlorite or mixed oxidant using rhodium/rhodium oxide mixed modified electrode. Aust J Basic Appl Sci 6(6):204-215

39. Ghernaout D, Ghernaout B, Boucherit A, Naceur MW, Khelifa A, Kellil A (2009) Study on mechanism of electrocoagulation with iron electrodes in idealized conditions and electrocoagulation of humic acids solution in batch using aluminum electrodes. Desalin Water Treat 8:91-99

40. Ratanatamskul C, Chiemchaisri C, Yamamoto K (1995) The use of a zeoliteiron column for residual ammonia and phosphorus removal in the effluent from a membrane process as an on-site small scale domestic wastewater treatment. Water Sci Technol 31(9):145-152

Publisher's Note Springer Nature remains neutral with regard to jurisdictional claims in published maps and institutional affiliations. 